\title{
Geographical Perceptions of the North in Pomponius Mela and Ptolemy
}

\author{
O.A.W. DILKE*
}

The Greeks and Romans were rather slow to change their views of the North which they had developed over hundreds of years. By 500 B.C., Hecataeus of Miletus described the idea of an encircling ocean, with the Rhipaean mountains north of the Danube, and the Hyperboreans living in the far North between these mountains and the ocean. All inhabitants of these areas tended, in the Greek world, to be called Scythians, but in fact Scythians inhabited southern Russia. As knowledge increased of the Dnieper, the Don, and the Caspian, and as through Alexander's conquest, even the Afghanistan area came to be known, the cartography of the European and west Asian North was sketched in by geographers. Pytheas of Marseilles, ca. 320 B.C., visited not only various parts of the British coasts, but also Thule, by which he may have meant part of the central Norwegian coast. He was also aware of an island, probably in the Baltic, from which amber came.
As a result of the abortive attempts of Augustus to establish a northern frontier of the Roman Empire extending from the Elbe to the Danube, classical authors learned more about the areas, and sometimes also the customs, of northern tribes. The chief descriptive work of this period is the Greek Geography of Strabo. A much shorter extant work of the same character, but in Latin, is that of Pomponius Mela, who was born in southern Spain. It was written between A.D. 40 and 43; the emperor described therein who was about to conquer Britain is either Gaius or Claudius. It is interesting to compare Mela's impression of the North, at times rhetorical and somewhat naive, with the more scientific approach of Ptolemy (Fig. 1), working from Alexandria between A.D. 127 and 150 . Ptolemy's title Geographike Hyphegesis may be translated "Manual of Geography". He explains that geography differs from chorography. (Mela's title) in that geography deals with

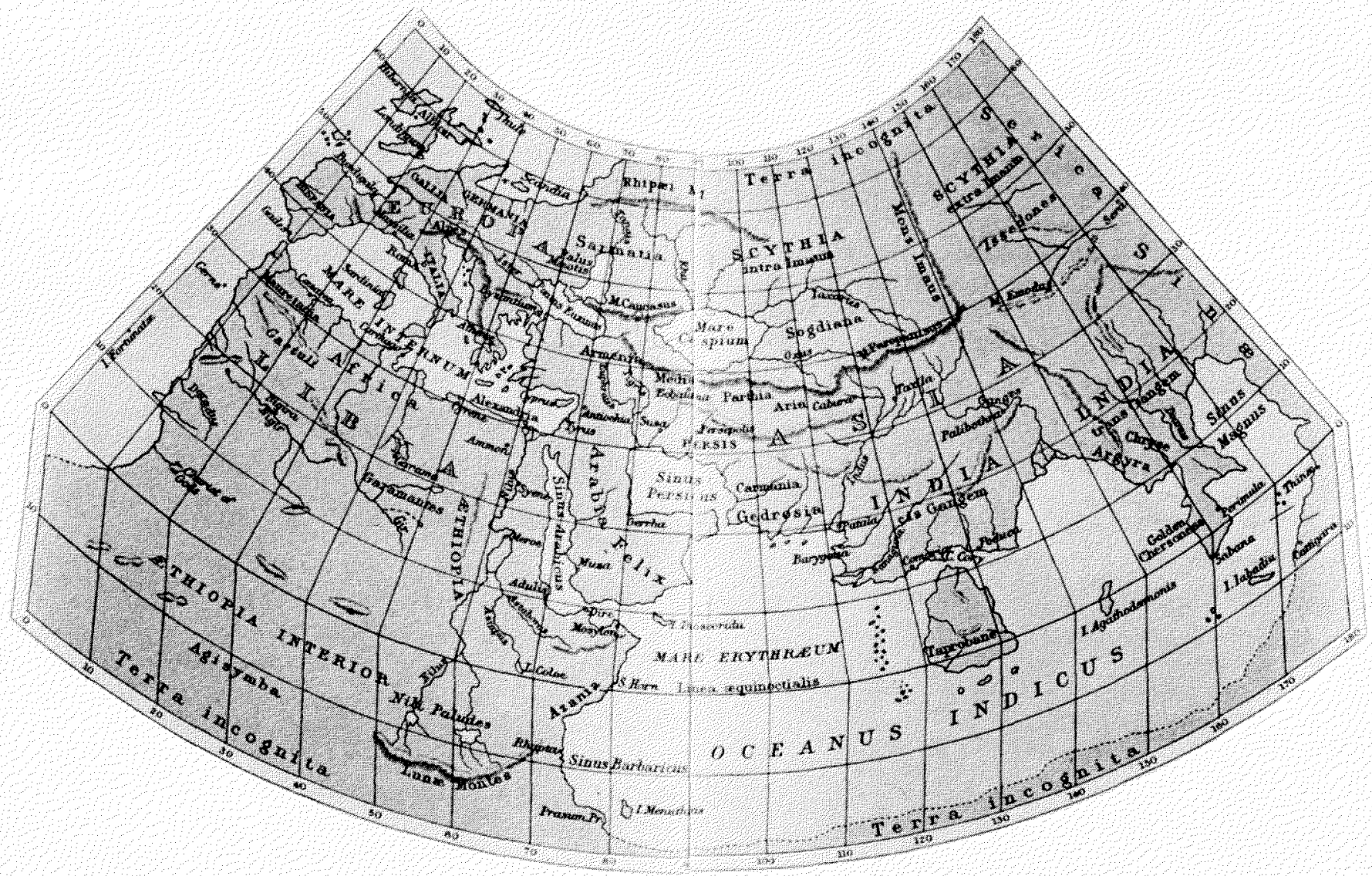

FIG 1 The world according to Ptolemy. 
the whole world, chorography with individual places or regions. But Mela, despite his title De chorographia, does attempt in a superficial way to cover the whole known world. Between the two chronologically are the geographical section of Pliny the Elder's Natural History and Tacitus' Germania.

Mela's work never became popular; extant manuscripts derive from the tenth-century Vaticanus Latinus 4929. Ptolemy's, by contrast, became so popular that there are dozens of manuscripts, some with and some without maps, the maps being transmitted in two recensions. Mela's world is surrounded by the sea and divided into two hemispheres, which correspond approximately to Asia on the one hand, Europe and Africa on the other. From north to south it is divided as it is in Eratosthenes' poem Hermes and Virgil's Georgics, into five zones - two cold, two temperate, and one hot. The ocean to the north is the Scythian Ocean; the Caspian, as in Eratosthenes, flows into it. The peoples furthest east, in Mela, are the Indians, Chinese (Seres), and Scythians. The last-named inhabit the Scythian shore of the ocean from the far East to the Caspian Gulf, except where they are deterred by cold.

Ptolemy's concept of the North was to a large extent influenced by Eratosthenes and his successors. The earth, he believed, was exactly spherical and could be measured. But it could not be completely mapped: everything beyond $63^{\circ} \mathrm{N}$, the latitude of Thule (Thyle), and about $17^{\circ} \mathrm{S}$, he regarded as terra incognita. Roman military expansion had shown that mainland Britain continued in some direction for about 1300 $\mathrm{km}$. If space in a straight line had had to be provided for mainland Scotland, its north coast would have reached about $65.5^{\circ} \mathrm{N}$, or $2.5^{\circ}$ north of Thule. Yet Thule, which for him was obviously the Shetland Islands, was known to be further north than John o' Groats. Since Eratosthenes had envisaged Albion as triangular, with the apex further east than the base, Ptolemy (Fig. 2) decided that north Scotland must be bent to extend considerably to the east. In this way neither Ireland, which he placed much too far north, nor Galloway, regarded by him in-

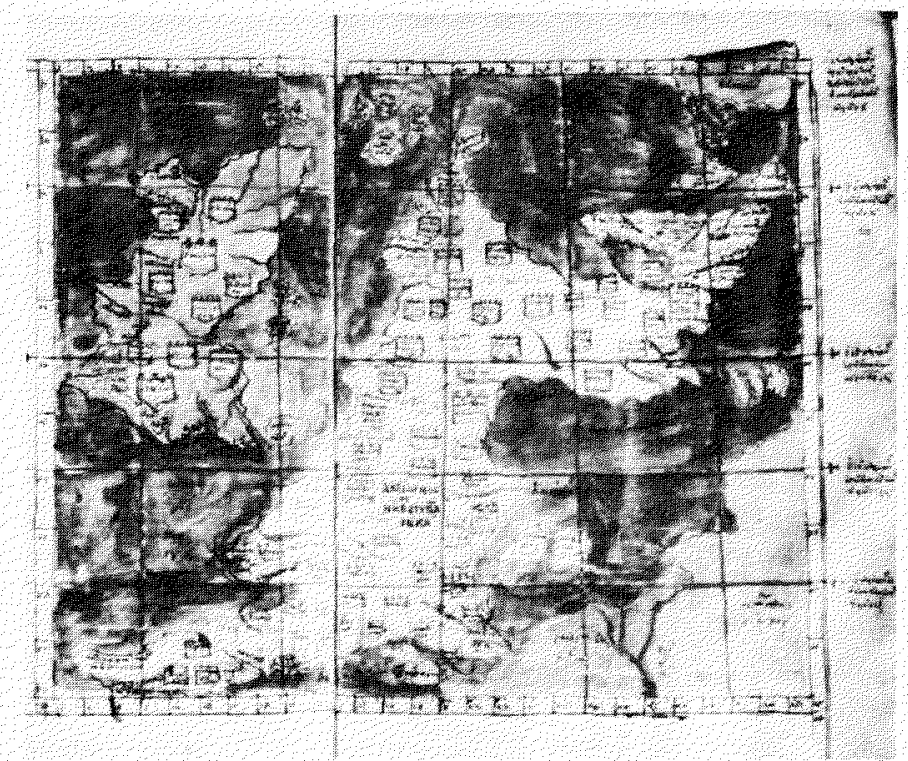

FIG, 2, Albion (Britain), miniature from Ptolemy's Geography. The British Library, Additional MS 19391, 19v-20r. correctly as the most northerly point of mainland Britain, extended beyond $61^{\circ} 40 \mathrm{~N}$.

There is a not-quite parallel situation for the continent of Europe (Fig. 3). Again $63^{\circ}$ is regarded by Ptolemy as the end of terra cognita, but he reckoned only $57.5^{\circ}$ as the latitude of the Rhipaean mountains (the reconstruction of $\mathrm{C}$. Müller, Tabulae, seems incorrect in adding Montes Hyperborei in Europe at latitude $61^{\circ} \mathrm{N}$ ). The name "Rhipaean" first occurs in Alcman, a lyric poet of the seventh century B.C., and is evidently derived from Greek rhipe, "gust of wind". The name "Hyperborean", as people first mentioned in Hesiod and supposed to have lived in the extreme North, occurs in Ptolemy as the name of the ocean to the north of Ireland. "Hyperborean" has been interpreted as meaning either "beyond the north wind", "beyond the mountains", or "carriers round [or] over". According to Delphic legend, Apollo spent the winter months with the Hyperboreans, and offerings from them, handed down from one tribe to another, eventually reached Apollo's shrine on the island of Delos. These offerings consisted not of amber, as used to be supposed, but, according to Callimachus, of ears of wheat. The mountain range (Sarmatian, according to Ptolemy) was thought to extend across much of Europe right into Asia (Fig. 4). It has no real equivalent; one might conjecture that the Urals were inserted several times, with correct or incorrect orientation, the latter as Hyperborean mountains. The major tributary of the Volga, the Kama, which to the ancients was "Rha orientalis", does have its upper course near the Urals, and this may have contributed to the confusion.

Pomponius Mela believed that the Riphaean [sic] mountain or mountains were in a very northerly part of Asia, near the source of the Don, "where there are permanent winters and intolerable cold. Scythian peoples inhabit it, almost all given the generic name of Belcae. On the Asiatic shore the nearest are the Hyperboreans, living beyond the north wind and the Riphaean mountains, beneath the very celestial pole (Mela, iii.36 sub ipso siderum cardine)..., where for six months there is continuous day, for six months continuous night." Mela records first the offerings to Apollo, then the Hyperboreans' custom of committing suicide by adorning themselves with garlands and jumping off a particular rock into the sea. There is obviously some confusion in the phrase "on the Asiatic shore", since the phrases immediately following seem to refer to the surrounding ocean, yet after the words "into the sea" (in pelagus) he goes on to describe the Caspian. As mentioned, it is clear from Book I that he regards the Caspian as having an outlet in the Scythian Ocean. Ptolemy does not make the same mistake: he merely errs on the shape of the Caspian.

Both thought of Scandinavia in terms of several islands. Pomponius Mela speaks emphatically of its size. He first (iii.31) describes the Codanus Gulf as lying beyond the Elbe, huge and dotted with large and small islands. He adds (iii.54): "In the gulf which we have called Codanus the outstanding island is Codannovia [Müllenhoff conjectured Scadinavia (sic)], still occupied by the Teutoni; it surpasses the other islands both in fertility and in size." His "Thyle"' is opposite the Belcae, which he said elsewhere was a synonym for 


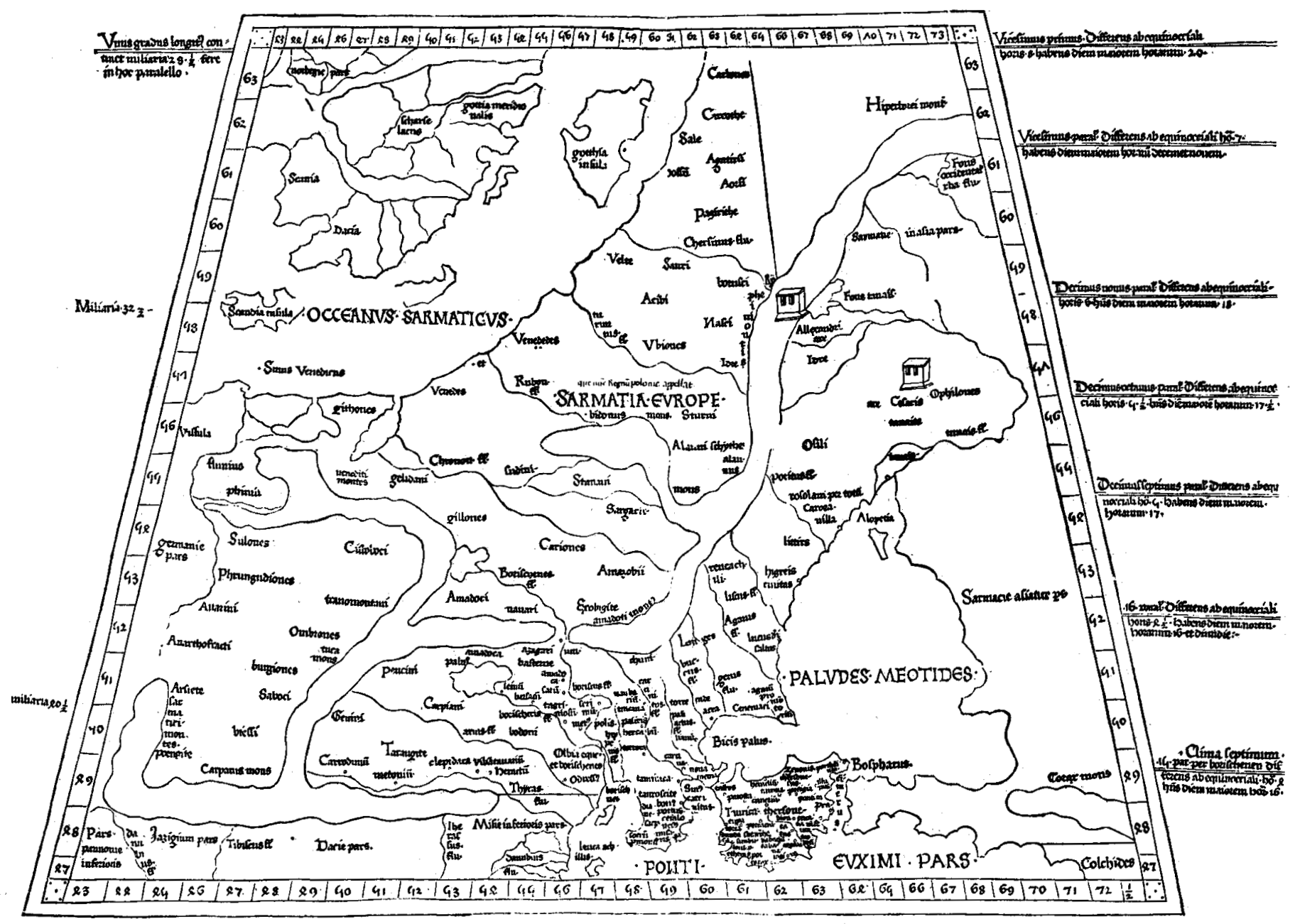

FIG. 3. Ptolemy's conception of Europe; Ulm, 1482. The Scandinavian lands postdate Ptolemy.

Scythians; so what area he means is far from clear. The name "Balcia", for the Baltic, comes, as we shall see, from Xenophon of Lampsacus; perhaps the Belcae were the in habitants of Balcia.

In Ptolemy there are islands called Skandiai (see Fig. 3), some small, the middle one lying at $57^{\circ} 40^{\prime}-58^{\circ} 30^{\prime} \mathrm{N}$, $43^{\circ}-46^{\circ} \mathrm{W}$. He then lists the seven tribes of this island, which owing to lack of space do not always appear on maps illustrating the Geography. G. Schütte, writing in 1917, considered that Ptolemy had a separate source for Scandinavia, since some of these.seven "tribes" can be identified: the Phinnoi are our Finns; the Khaideinoi have taken on the name of Hedemarken in Norway; and the Goutai have given Gotland. For J. Svennung (1974) they are our Lapps, the Heinnir and the Gutar. Whether we can hazard further identifications is uncertain, except that the Daukiones (Dankiones) might be the Danes.

The great number of tribes recorded by Ptolemy in what are today the USSR and Poland can in fact be reduced because of probable duplication. Duplication or similarity of names is obvious, and these "pairs" were analyzed by Schütte, who concluded that Ptolemy. was relying on two cartographic sources. But the evidence does not seem to indicate, as Schütte claimed, that the orientation of Ptolemy's source $\mathrm{E}$ has been rotated counterclockwise by $90^{\circ}$.

A number of these tribes, like those of some of the more southerly latitudes, have names formed of Greek or in one case (Transmontani) Latin compounds. In some of these we perceive an element of mythological fancy, arising out of travellers' tales. Pliny, in his Natural History (iv. 95), writes: "Xenophon of Lampsacus reports that three days' sail from the Scythian coast there is an island of enormous size called Balcia; Pytheas gives its name as Basilia [royal?].' He then recounts stories presumably from the same source, of the Oeonae, Hippopodes, and Panotii (these last appearing in his manuscripts as "Fanesii"). The Hippopodes are men with horses' feet, and for the benefit of readers unfamiliar with Greek, Pomponius Mela so defines them. In this category one need not agree with Schütte that Exobygitai in Ptolemy is a corruption of Hamaxobioi Skythai, "Scythians (nomads) living in carts", since exo is also a Greek prefix, "outside". Mela (iii. 59) mentions Androphagoe (cannibals) living together with Sacae, in an area in Asiatic Scythia uninhabitable because of prevalent diseases. Near the horse-footed men, according to the same writers, live Sannali (again Panotii or 


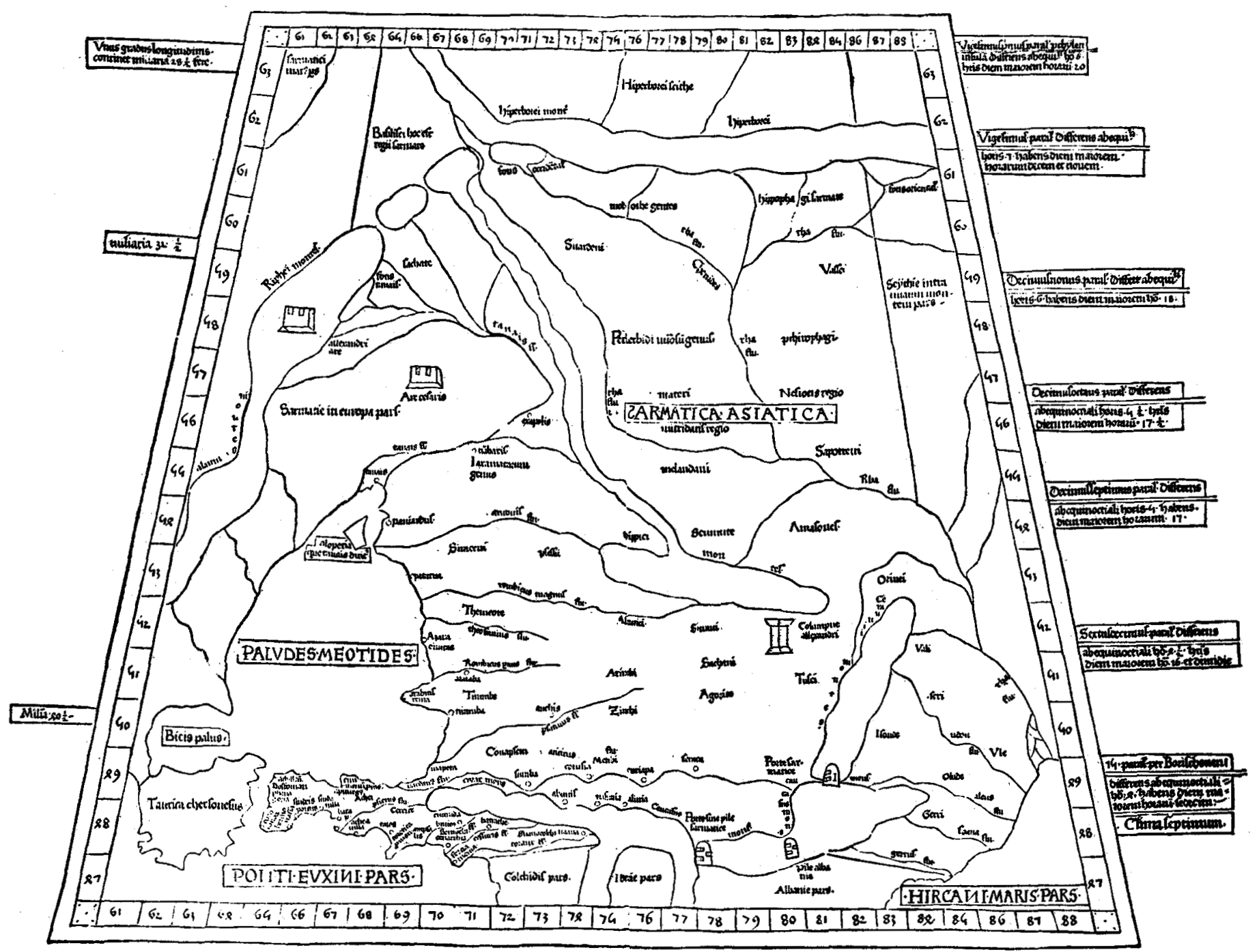

FIG. 4. Ptolemy's conception of Asia; UIm, 1482.

Panuatii has been conjectured), who have big ears covering the whole of their bodies, which are otherwise naked. This too, if we follow the conjecture, is a Greek compound, "all ear"; T. Pekkanen compares the Indian Karnapravāranāh. There are also Oeonae, who eat only birds' eggs and oats.

Mela describes Thyle as the darkest place in winter and the lightest in summer. The area corresponding to Siberia was, to Mela, impassable because of snow and uncultivated because of the savagery of the inhabitants, and beyond that he describes huge areas plagued by wild animals. North of the Caspian live Amazons (these are more often placed south of the Black Sea, where he also mentions them) and, still further north, Hyberborei.

In analyzing the perceptions of the North in Ptolemy's Manual of Geography, we have naturally ignored cartographic additions made during the Renaissance. But one fantastic claim must be countered, since if it were true it would reverse our ideas of what was known about the Arctic and Antarctic in the earliest times. C.H. Hapgood, in his work Maps of the Ancient
Sea Kings, published some 15 years ago, tries to trace the history of cartography to a very remote period of prehistory. He starts from the Zeno map and from a fifteenth-century Vatican map intended to amplify Ptolemy's work. His conclusion, "If the original source of the Ptolemy map came from the end of the ice age, that of the Zeno map may have originated much earlier"' (p. 167), represents in my view an abandonment of the scientific approach. (1) It is not true, as Hapgood claims, that "some authorities have considered that they [Ptolemaic maps] were reconstructed from the table [the coordinates]... in the 15th century." If there was such a reconstruction, it was made much earlier, probably in Constantinople; our most accurate map corresponding to the coordinates is Vaticanus Urbinas Graecus 82, now usually dated to the late thirteenth century. (2) It does not follow, because some parts of a Ptolemaic map are given place-names and other parts are not, that they are by two different hands. It was and still is a convention to leave unlabelled the parts of a map which are not covered by the title. (3) The Zeno map is no longer thought to date from 
1380 , as was claimed by Niccolò Zeno the younger, but from much later. (4) Finally, to assume that at the end of the Ice Age man knew the remotest thing about cartography of the polar regions is ludicrous.

Ptolemy's geography is often criticized today as being too full of mistakes. By comparing it with that of a writer such as Pomponius Mela, we can see that it represented an enormous advance. Shortly after the time when Mela was writing, Britain became a Roman province. Agricola, during his campaigns in Britain (A.D. 78-84), not only marched northwards as far as the Moray Firth, but also circumnavigated Britain and sent a Greek schoolmaster, Demetrius of Tarsus, to find out as much as he could about the Scottish isles. Trajan, by adding Dacia to the Roman Empire, increased knowledge of the tribes beyond the Danube. Marinus of Tyre drew up a map of the world which was perhaps still circulating in the time of alMas'udi, who died in 956. Ptolemy much criticized this map, but he also used it freely. Moreover, during all this time Roman roads were increasing in number, so that by studying Agrippa's world map, itineraries, road maps, and surveyors' maps Ptolemy was able to blend Greek theory with Roman practice. Even if the far North and the far South were his weak points, that should not blind us to his accomplishment in establishing the topography of many other regions. 